Original Research Paper

\title{
Pembinaan Masyarakat dalam Budidaya Tanaman Cabai Rawit dengan Sistem Bedengan Lahan dan Aplikasi Mulsa Plastik
}

\author{
Ahmad Raksun ${ }^{1 *}, \operatorname{Karnan}^{1}$ \\ ${ }^{1}$ Program Studi Pendidikan Biologi Fakultas Keguruan dan Ilmu Pendidikan, Universitas Mataram
}

*Corresponding Author: Ahmad Raksun, Program Studi Pendidikan Biologi Fakultas Keguruan dan Ilmu Pendidikan, Universitas Mataram, Indonesia;

Email:

ahmadunram@unram.ac.id

Abstrak: Masyarakat tani Dusun Mertak Umbak Desa Mertak Tombok Kecamatan Praya Kabupaten Lombok Tengah masih memiliki pengetahuan tentang budidaya pertanian yang rendah. Rendahnya pengetahuan masyarakat berdampak pada rendahnya hasil usaha pertanian yang mereka peroleh. Oleh karena itu diperlukan pembinaan masyarakat tani Dusun Mertak Umbak tentang usaha pertanian berbasis agribisnis. Salah satu tanaman yang mempunyai nilai ekonomi tinggi dan dapat dikembangkan di Dusun Mertak Umbak adalah tanaman cabai rawit. Masalah-masalah utama yang dihadapi oleh masyarakat tani Dusun Mertak Umbak adalah: (1) Hasil usaha pertanian yang diperoleh masyarakat tani Dusun Mertak Umbak masih tergolong rendah, (2) masyarakat tani Dusun Mertak Umbak tidak memiliki pengetahuan dan keterampilan tentang budidaya tanaman cabi rawit dengan sistem bedengan dan aplikasi mulsa plastik, (3) masyarakat tani Dusun Mertak Umbak tidak memiliki pengetahuan dan keterampilan tentang pemupukan tanaman cabai rawit menggunakan kompos. Dalam upaya mengatasi masalah pertama maka tim memberikan solusi dengan membudidayakan tanaman yang mempunyai nilai ekonomi tinggi yaitu tanaman cabai rawit. Untuk mengatasi permasalahan kedua maka tim memberikan solusi dengan melakukan pembinaan masyarakat tani dalam budidaya tanaman cabai rawit dengan sistem bedengan dan aplikasi mulsa plastik. Selanjutnya untuk mengatasi permasalahan ketiga, tim memberikan solusi dengan melakukan pendampingan masyarakat dalam melakukan pemupukan tanaman menggunakan kompos. Hasil pengabdian masyarakat ini adalah: (1) masyarakat Dusun Mertak Umbak Desa Mertak Tombok yang menjadi mitra kegiatan ini memiliki pengetahuan dan keterampilan membudidayakan cabai rawit dengan sistem bedengan lahan dan aplikasi mulsa plastik, (2) Mitra memiliki pengetahuan dan keterampilan tentang teknik pembuatan kompos, (3) mitra memiliki respons yang baik terhadap pelaksanaan kegiatan dan berkomitmen untuk moncoba memanfaatkan kotoran ternak yang ada disekitarnya sebagai bahan baku pembuatan kompos. Selanjutnya menggunakan kompos untuk meningkatkan hasil panen tanaman pada lahan pertanian yang mereka miliki

Kata Kunci: Pembinaan masyarakat, budidaya cabai rawit, bedengan lahan dan mulsa plastik

\section{Pendahuluan}

Cabai rawit (Capsicum frutecens L.) merupakan salah satu tanaman hotikultura yang buahnya banyak dibutuhkan masyarakat terutama di Pulau Lombok. Buah cabai rawit banyak dimanfaatkan pada industri makanan, minuman dan farmasi. Tanaman caabai rawit dapat dibudidayakan pada dataran rendah maupun dataran tinggi. Cabai rawit dapat tumbuh pada berbagai jenis tanah yang ada pada lahan pertanian.
Untuk memperoleh kuantitas dan kualitas produksi yang baik maka sifat fisika, kimia, biologi dan kesuburan tanah perlu mendapat perhatian. Salah satu upaya yang dapat dilakukan untuk meningkatkan pertumbuhan dan produksi tanaman adalah dengan melakukan pemupukan tanaman.

Dusun Mertak Umbak terlerak di Desa Metak Tombok Kecamatan Praya Kabupaten Lombok Tengah Propinsi Nusa Tenggara Barat. Secara umum masyarakat tani Dusun Mertak Umbak memiliki penghasilan yang rendah. Rendahnya 
penghasilan masyarakat Dusun Mertak Umbak terutama disebabkan oleh rendahnya hasil panen tanaman yang dibudidayakan masyarakat sebagai dampak dari minimnya pengetahuan masyarakat dalam mengembangkan usaha pertanian. Dalam mengembangkan usaha pertanian, masyarakat selalu menanam padi 2 kali setahun, selanjutnya menanam kacang tanah atau jagung. Dalam budidaya tanaman padi dan tanaman lainnya, masyarakat Dusun Mertak Umbak Selalu menggunakan pupuk kimia. Penggunaan pupuk kimia secara terus menerus tampa adanya pemberian bahan organik pada lahan pertanian pada kenyataannya menyebabkan terjadinya ketergantungan lahan pertanian terhadap pupuk kimia sehingga kebutuhan pupuk kimia makin lama makin tinggi. Makin tingginya kebutuhan pupuk kimia menyebabkan biaya usaha pertanian makin lama juga makin tinggi.

Sebagian masyarakat tani Dusun Mertak Umbak memiliki usaha sampingan yaitu beternak kambing dan atau sapi. kambing dan sapi yang dimiliki oleh anggota masyarakat Dusun Mertak Tombok dipelihara dengan cara dikandangkan disamping rumah masing-masing pemilik ternak. Kegiatan peternakan kambing dan sapi yang dilakukan oleh masyarakat Dusun Mertak Tombok menghasilkan limbah berupa kotoran ternak. Banyaknya kotoran ternak dilingkungan sekitar Dusun Mertak Tombok menyebabkan terjadinya masalah lingkungan.

Untuk meningkatkan pendapatannya, masyarakat tani Dusun Mertak Umbak perlu melakukan usaha pertanian yang berbasis agribisnis. Komoditi yang mempunyai nilai jual tinggi di Pulau Lombok adalah cabai rawit. Oleh karena itu tim pengabdian melakukan pengabdian psds masyarakat tentang pembinaan masyarakat dalam budidaya tanaman cabai rawit dengan teknik bedengan lahan dan aplikasi mulsa plastik yang dilaksanakan di Dusun Mertak Umbak Desa Mertak Tombok Kecamatan Praya Kabupaten Lombok Tengah

Kegiatan Pengabdian pada masyarakat ini bertujuan untuk: (1) mentranfer pengetahuan dan keterampilan kepada masyarakat tani tentang budidaya tanaman cabai rawit dengan sistem bedengan dan aplikasi mulsa plastik. (2) mentransfer pengetahuan dan keterampilan kepada mitra tentang teknik pemupukan tanaman menggunkan kompos untuk meningkatkan pertumbuhan dan produksi tanaman. Selanjutnya manfaat kegiatan pengabdian pada masyarakat ini adalah (1) masyarakat tani Dusun Mertak Tombok memiliki pengetahuan dan keterampilan tentang budidaya tanaman cabai rawit dengan teknik bedengan lahan dan aplikasi mulsa plastik, (2) masyarakat tani Dusun Mertak Tombok memiliki pengetahuan dan keterampilan tentang teknik pemupukan tanaman menggunakan kompos.

\section{Metode Pelaksanaan}

Kegiatan ini terdiri atas 6 tahapan, yaitu: (1) sosialisasi, (2) tranfer pengetahuan teoritis pengolahan lahan, (3) transfer pengetahuan teoritis tentang teknik pembuatan kompos, (4) transfer keterampilan pembuatan kompos, (5) transfer pengetahuan dan keterampilan tentang pemasangan mulsa plastik pada bedengan lahan (6) pendampingan masyarakat dalam budidaya tanaman cabai rawit. Kegiatan sosialisasi, tranfer pengetahuan teoritis pengolahan lahan dan transfer pengetahuan tentang teknik pembuatan kompos dilakukan dengan metode ceramah dan diskusi. Selanjutnya kegiatan transfer keterampilan pembuatan kompos, transfer pengetahuan dan keterampilan tentang pemasangan mulsa plastik pada bedengan lahan dan budidaya tanaman cabai rawit dilakukan dengan metode ceramah, diskusi dan pendampingan.

Pengolahan kotoran ternak menjadi kompos dilakukan dengan langkah-langkah sebagai berikut: (1) menyiapkan semua alat dan bahan yang diperlukan, (2) membuat bak fermentasi berupa galian tanah berukuran panjang : lebar : dalam galian $=5 \mathrm{~m}: 2 \mathrm{~m}: 1 \mathrm{~m}$, (3) menjemur kotoran kotoran kambing dan kotoran sapi pada terik matahari menggunkan wadah terpal sampai kering, (4) mencampur kotoran kambing dan kotoran sapi dengan perbandingan volume 1: 1, (5) mencampur campuran kotoran kambing dan sapi dengan dedak dan sekam dengan perbandingan volume $(10: 1: 5)$ (6) membasahi campuran seluruh bahan baku kompos dengan air sumur (7) memfermentasikan bahan baku kompos pada bak fermentasi yang tersedia selama 6 minggu, (7) mengangkat kompos dari bak fermentasi 
Kegiatan berikutnya adalah membimbing mitra melakukan pemupukan tanaman menggunakan kompos. Penggunaan kompos pada tanaman cabai rawit dilakukan dengan tahapan kerja sebagai berikut: (1) melakukan pembibitan cabai rawit menggunakan pot pembibitan, (2) membersihkan lahan aplikasi kompos, (3) membonkar lahan menggunkan cangkul, (4) membuat bedengan dengan lebar $90 \mathrm{~cm}$ dan panjang 12 meter, (5) meberikan kompos pada setiap bedengan lahan dengan dosis $18 \mathrm{~kg}$ per bedengan, (6) mencampur kompos dengan media tanah pada bedengan sampai tercampur secara merata, (7) menutup bedengan dengan mulsa plastik hitam perak, (8) melubangi mulsa plastik hitam perak, (pada setiap bedengan dibuat 2 baris lubang), jarak lubang pada setiap baris $=100 \mathrm{~cm}$, (9) menanam bibit cabai rawit yang sudah disiapkan pada bedengan lahan.

Solusi permasalahan yang dihadapi mitra mengacu pada hasil-hasil penelitian yang sudah dilkukan oleh sejumlah peneliti. Hasil penelitian Huda et al (2016) menunjukkan bahwa aplikasi kompos azolla dan azolla segar sebagai pupuk organik memberikan pengaruh nyata terhadap pertumbuhan tanaman wortel pada parameter panjang tanaman, tinggi tanaman, jumlah daun dan indeks luas daun. Tanaman Alpinia malaccencis yang mendapat input nutrisi berupa kompos bioposka sebanyak $75 \%$ memiliki pertumbuhan vegetatif yang lebih cepat pada parameter tinggi tanaman, diameter batang, panjang daun, lebar daun dan jumlah daun dibandingkan dengan perlakuan lainnya (Rivai dan Wardani, 2017). Pemberian kompos berpengaruh nyata terhadap tinggi tanaman, umur berbunga, umur panen dan berat buah cabai rawit (Maruli et al, 2012). Interakasi urea dan kompos berpengaruh nyata terhadap pertumbuhan jagung tongkol ganda (Muyassir, 2013). Kompos bilotong mampu meningkatkan waktu berbunga, jumlah buah pertanaman, dan bobot buah per hektar tanaman tomat (Nisaa et al, 2017). Aplikasi kompos yang dicampur dengan topsoil sebagai media tanam dengan dosis $1 / 2$ atau 2/3 bagian dari media yang dikombinasikan dengan pupuk NPK 2 gr per bibit dapat meningkatkan tinggi dan diameter rata-rata bibit meranti tembaga asal cabutan alam sebesar $72 \%$ dan $42 \%$ dibandingkan tanpa kompos dan pupuk (Junaedi, 2012). Dosis kompos berpengaruh nyata terhadap tinggi tanaman sawi pada umur 16 dan 40 hari setelah tanam (Habibi et al, 2017). Perlakuan kompos 1, 2 dan $3 \mathrm{~kg}$ lubang $\operatorname{tanam}^{-1}$ memperlihatkan tinggi tanaman jumlah anakan, panjang daun dan lebar daun yang berbeda nyata dibandingkan dengan kontrol (Burhanudin et al, 2016).

Sejalan dengan hasil penelitian di atas Indriyati (2005) menyimpulkan bahwa pemberian pupuk kompos mampu meningkatkan pertumbuhan dan produksi padi di lahan pasang surut sulfat masam. Interaksi antara pupuk NPK dan pupuk kompos memberikan pengaruh nyata terhadap pertumbuhan gmelina baik tinggi maupun diameter (Wasis dan Fathia, 2010). Kompos UB berpengaruh nyata terhadap tinggi tanaman, jumlah daun, bobot segar total tanaman sawi dan bobot segar total kosumsi sawi. Perlakuan kompos UB menghasilkan tinggi tanaman sawi $18,26 \mathrm{~cm}$, bobot segar total tanaman sawi 39,24 g dan bobot segar total konsumsi sawi 25,55 g, lebih tinggi jika dibandingkan dengan tanpa kompos (Atari et al, 2017). Kedelai varietas galunggung merespon secara signifikan terhadap kompos limbah kelapa sawit, produksi meningkat secara sigifikan (Darma, 2000). Aplikasi kompos pada lahan pertanian Desa Montong Are berpengaruh signifikan terhadap pertumbuhan tomat (Raksun dan Mertha, 2017). Perlakuan tanah: kompos : pupuk kandang (1:3: 1) memberikan hasil terbaik pada parameter tinggi tanaman, jumlah stolon, jumlah buah panen, diameter buah dan derajat kemanisan pada tanman stroberi dibandingkan dengan perlakuan tanpa kompos (Sipayung et al, 2016). Pemberian kompos berpengaruh nyata terhadap tinggi tanaman, panjang daun, lebar daun, diameter batang, waktu muncul bunga jantan dan bunga betina, panjang tongkol dan jumlah biji tanaman jagung manis (Syafriliandi et al, 2016). Media tanam dengan komposisi kompos dan tanah $(1:$ 2) dan penambahan pupuk $\mathrm{M}_{10}$ pada konsentrasi $20 \mathrm{ml}$ mampu meningkatkan diameter batang $(2,29 \mathrm{~mm})$ sedangkan pada konsentrasi $15 \mathrm{ml}$ meningkatkan produksi tongkol (1,66 buah) tanaman jagung saat panen (Elpawati et al, 2015).

\section{Hasil dan Pembahasan}

Kegiatan pengabdian pada masyarakat ini bertujuan untuk: (1) mentranfer pengetahuan dan 
keterampilan kepada masyarakat tentang budidaya tanaman cabai rawit dengan sistem bedengan lahan dan aplikasi mulsa plastik. (2) mentransfer pengetahuan dan keterampilan kepada mitra tentang teknik pembuatan kompos, (3) mentransfer pengetahuan dan keterampilan kepada mitra tentang teknik pemupukan tanaman menggunkan kompos untuk meningkatkan pertumbuhan dan produksi tanaman.

Dalam upaya mencapai tujuan di atas maka dalam pengabdian pada masyarakat ini dilakukan kegiatan dengan tahapan-tahapan: (1) sosialisasi, (2) tranfer pengetahuan teoritis pengolahan lahan, (3) transfer pengetahuan teoritis tentang teknik pembuatan kompos, (4) transfer keterampilan pembuatan kompos, (5) transfer pengetahuan dan keterampilan tentang pemasangan mulsa plastik pada bedengan lahan (6) pendampingan masyarakat dalam budidaya tanaman cabai rawit.

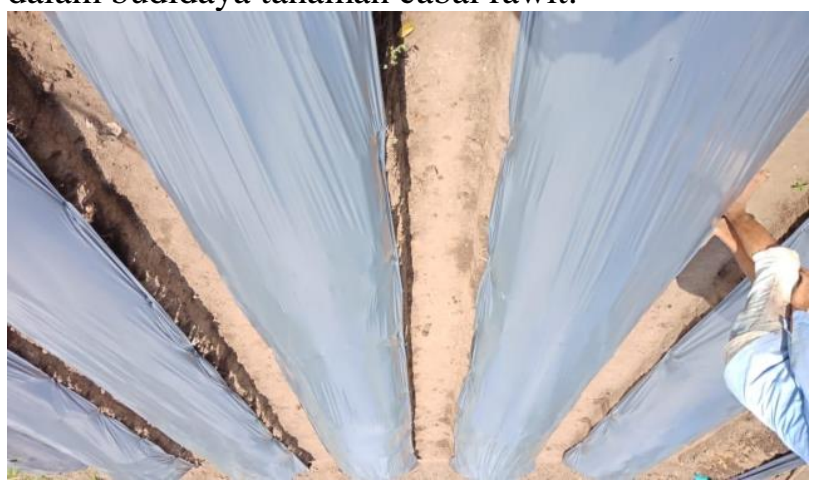

Gambar 1. Bedengan lahan yang sudah ditutup mulsa plastik

Pada saat pelaksanaan kegiatan ini nampak bahwa masyarakat Dusun Mertak Tombok yang menjadi mitra kegiatan ini telaah mengikuti kegiatan pengabdian pada masyarakat dengan baik mulai dari sosialisasi kegiatan sampai pada saat penyampain materi pengabdian. Hal ini dapat dilihat dari banyaknya pertanyaan yang diajukan peserta yang terkait dengan materi yang disampaikan tim pelaksana pada saat diskusi.

Selain itu pada saat praktek pembuatan kompos semua peserta ikut berperan secara aktif sehingga kegiatan paraktek pembuatan kompos dapat berjalan lancar. Kegiatan pengabdian seperti ini sangat penting artinya bagi masyarakat Dusun Mertak Tombok karena melalui kegiatan ini mereka dapat memahami berbagai dampak yang mungkin timbul sebagai akibat banyaknya sampah yang dihasilkan dari berbagai aktivitas masyarakat seperti kegiatan usaha pertanian dan peternakan.
Selanjutnya mereka diharapkan dapat melakukan pencegahan terhadap dampak tersebut dengan tidak membuang sampah disembarang tempat dan memanfaatkan sampah pertanian dan sampah peternakan sebagai bahan baku pembuatan kompos untuk meningkatkan pertumbuhan dan produksi tanaman yang dibudidayakan di pekarangan rumah, kebun dan lahan persawahan.

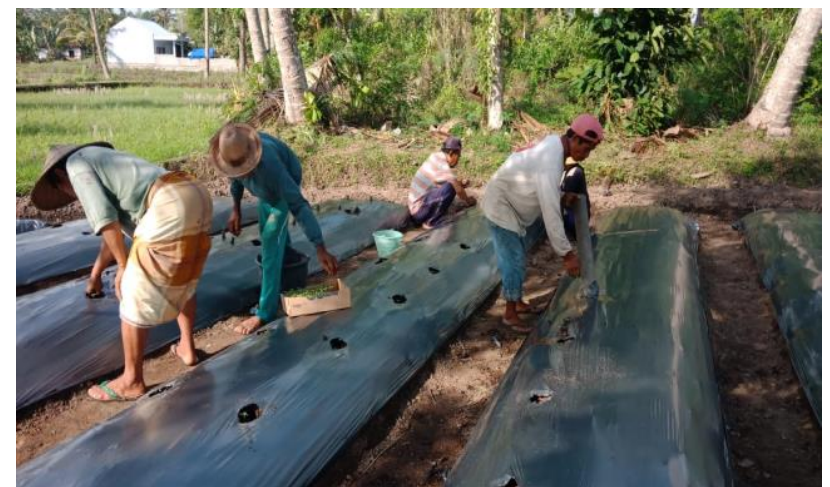

Gambar 2. Masyarakat binaan sedang menanam Cabai Rawit

Setelah selesai pembuatan kompos dengan bahan baku sampah organik, kegiatan pengabdian pada masyarakat dilanjutkan dengan penggunaan kompos sebagai pupuk pada lahan pertanian untuk meningkatkan hasil panen tanaman cabai rawit. Pemupukan tanaman menggunakan kompos dilakukan pada tanaman cabai rawit dengan langkah kerja sebagai berikut: (1) pembibitan tanaman cabai rawit, (2) membersihkan rumput liar (gulma) pada lahan yang akan ditanami cabai rawit menggunakan sabit, (3) pembongkaran lahan menggunkan cangkul, (4) pembuataan bedengan pada lahan yang akan ditanami tanaman cabai rawit, (5) pemberian kompos pada bedengan dengan dosis 1,5 $\mathrm{kg}$ kompos per $1 \mathrm{~m}^{2}$ lahan, (6) mencampur tanah pada bedengan dongan kompos sampai tercampur secara merata, (7) menutup bedengan dengan mulsa plastik hitam perak, (8) menanam bibit cabai rawit yang sudah disiapkan pada bedengan lahan, (9) melakukan perawatan tanaman cabai rawit (10) panen tanaman cabai rawit

Masyarakat Dusun Mertak Umbak Desa Mertak Tombok yang menjadi mitra kegiatan pengabdian pada masyarakat ini memilki pekerjaan utama sebagai petani dengan menanam berbagai jenis tanaman seperti padi, kacang tanah, jagung, kacang kedelai dan lain-lain. Selain melakukan 
usaha pertanian pada lahan persawahan mereka memiliki usaha sampingan yaitu beternak itik, kambing dan sapi. Disekitar tempat tinggal mereka, terdapat banyak kotoran ternak dan sisa makanan ternak yang sampai saat ini masih belum dapat mereka olah menjadi suatu produk yang bermanfaat. Kotoran ternak dan sisa makanan ternak dibuang kekali sehingga mencemari air kali. Kondisi tersebut merupakan faktor pendorong bagi peserta dalam mengikuti kegiatan ini. Melalui kegiatan ini, mereka memahami dan menyadari bahwa jika sampah yang mereka hasilkan dibuang disembarang tempat dapat menimbulkan berbagai dampak negatif bagi lingkungan. Dengan demikian mereka memiliki keinginan yang kuat untuk menjadi peserta kegiatan ini dan memanfaatkan sampah kotoran ternak yang ada disekitar tempat tinggal mereka sebagai bahan baku pembuatan kompos serta memanfaatkan kompos untuk meningkatkan pertumbuhan tanaman pada lahan persawahan, kebun dan pekarangan yang mereka miliki. Selain itu pengolahan sampah peternakan menjadi kompos dapat meningkatkan kebersihan lingkungan.

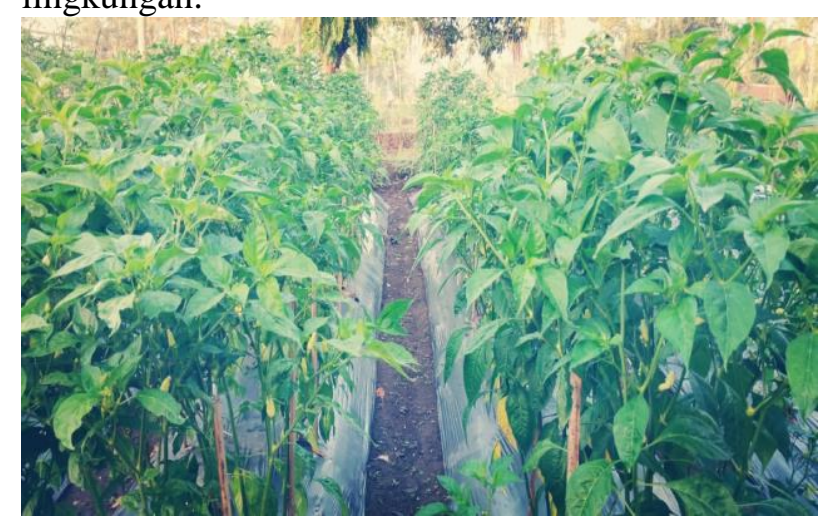

Gambar 3. Cabai Rawit Umur 38 Hari Setelah Tanam

Faktor penghambat kegiatan ini adalah adaanya kesulitan dalam menentukan waktu pelaksanaan kegiatan Masyarakat yang menjadi mitra pelaksanaan pengabdian ini memiliki kesibukan dalam menyelesaaikan pekerjan rutinnya setiap hari seperti mengolah lahan pertanian dan mencari makanan ternak sehingga tim merasa kesulitan dalam menentukan waktu pelaksanaan kegiatan. Demikian juga tim pelaksana memiliki kesibukan dengan kegiatan perkuliahan di kampus Universitas Mataram. Kondisi ini menyebabkan terjadinya kesulitan dalam menentukan waktu pelaksanaan kegiatan. Tim pengabdian dan masyarakat harus membuat kesepakatan waktu pelaksanaan kegiatan dengan cermat agar waktu pelaksanaan kegiatan pengabdian tidak berbenturan dengan waktu perkuliahan di Universitas Mataram.

Faktor penghambat lainnya adalah kurangnya air disekitar lokasi pelaksanaan pengabdian karena kegiatan ini dilakukan pada musim kemarau. Faktor penghambat ini dapat diatasi dengan memamfaatkan air yang ada pada kolam salah seorang warga. Air tersebut dialirkan ke lahan penanaman cabai rawit dengan menggunakan selang dan pompa air.

\section{Kesimpulan}

Seluruh rangkaian kegiatan mulai dari sosialisasi kepada kelompok masyarakat sasaran sampai dengan berakhirnya pelaksanaan kegiatan ini telah dilaksanakan dengan baik dan lancar. Dalam pelaksanakan kegiatan ini dapat disimpulkan bahwa:

1. Masyarakat Dusun Mertak Umbak Desa Mertak Tombok Kecamatan Peraya Kabupaten Lombok Tengah yang menjadi mitra kegiatan pengabdian ini memiliki pengetahuan dan keterampilan tentang teknik pengolahan sampah organik kotoran sapi dan kotoran kambing menjadi kompos.

2. Mitra kegiatan pengabdian masyarakat memiliki pengetahuan dan keterampilan tentang teknik pemupukan tanaman menggunakan kompos.

3. Mitra kegiatan ini memiliki pengetahuan dan keterampilan membudidayakan cabai rawit dengan sistem bedengan lahan dan aplikasi mulsa plastik

4. Mitra kegiatan ini memiliki respons yang sangat baik terhadap pelaksanaan kegiatan dan berkomitmen untuk moncoba memanfaatkan sampah pertanian dan peternakan terutama kotoran ternak yang ada disekitarnya sebagai bahan baku pembuatan kompos. Selanjutnya menggunakan kompos untuk meningkatkan hasil panen tanaman yang ada di pekarangan maupun pada lahan pertanian yang mereka miliki 


\section{Ucapan Terimakasih}

Terimakasih kami sampaikan kepada Ketua LPPM Universitas mataram yang telah memfasilitasi pelaksanaan kegiatan pengabdian pada masyarakat ini. Terimakasih juga kami sampaikan kepada semua pihak yang telah memberikan bantuan terhadap pelaksanaan kegiatan ini

\section{Daftar Pustaka}

Atari, N., Murdiono, W.E., dan Koesriharti. 2017. Pengaruh Kompos UB dan Pupuk Nitrogen terhadap Pertumbuhan dan Hasil Tanaman Sawi Bunga. Produksi Tanaman. Vol 5 (12): 1936 - 1941.

Burhanudin, Yudarfis dan Idris, H. 2016. Pengaruh Pemberian Kapur dan Kompos terhadap Pertumbuhan dan Produksi Jahe Putih Besar pada Tanah Podsolik Merah Kuning. Bul Littro Vol 27 (1): 47 - 53

Darma, S. 2000. Respon Tanaman Kedelai Terhadap Kompos Limbah Kelapa Sawit pada Dosis Berbeda. Budidaya Pertanian. Vol 6 (2): 96 - 104

Elpawati, Dara, S.D. dan Dasumiati. 2015. Optimalisasi Penggunaan Pupuk Kompos dengan Penambahan Effective Microorganism $10 \quad\left(\mathrm{EM}_{10}\right) \quad$ pada Produktivitas Tanaman Jagung. Alkauniyah. Vol 8 (2): 77 - 87

Habibi, Z., Satriawan, H dan Agusni. 2017. Pengaruh Dosis Kompos Terhadap Pertumbuhan tanaman sawi (Brassica rapa). Agrotropika Hayati. Vol. 4(4): 305 313.

Huda, M.S., Widaryanto, E. dan Nugroho, A. 2016. Pengaruh Beberapa Dosis Kompos dan Azolla (Azolla pinnata R.B.) Segar pada Pertumbuhan dan Hasil 2 Varietas Tanaman Wortel (Daucus carrota) L.). Produksi Tanaman. Vol 4 (6): 431 - 437
Indriyati, L. 2005. Pengolahan Jerami Padi pada Pertanaman Padi Lahan Pasang Surut Sulfat Masam. Abstrak Hasil Penelitian Pertanian Indonesia Pusat Perpustakaan dan Penyebaran Hasil Penelitian Indonesia. Vol. 12 (2) Bogor.

Junaidi, A. 2012. Pengaruh Kompos dan Pupuk NPK terhadap Peningkatan Kualitas Bibit Cabutan Miq. Penelitian Hutan dan Konservasi Alam. Vol. 9 (4): 373 - 383

Maruli, Ernita dan Gultom, H. 2012. Pengaruh Pemberian NPK Grower dan Kompos terhadap Pertumbuhan dan Produksi Tanaman Cabai Rawit (Capsicum frustencen L.). Dinamika Pertanian. Vol 27 (3): $149-155$

Muyassir. 2013. Respon Jagung Tongkol Ganda terhadap Pemupukan Urea dan Kompos. Manejemen Sumberdaya Lahan. Vol 2 (3): $250-254$.

Nisaa, B., Sudiarso dan Ainin N. 2017. Aplikasi NPK Majemuk dan Kompos Bilotong untuk Meningkatkan Pertumbuhan dan Hasil Tomat (Solanum lycopersicum) Ditanaman Diantara Kubis (Brassica Oleracea). Produksi Tanaman Vol 5 (6): $925-931$

Raksun, A. dan Mertha, I.G. 2017. Pengaruh Kompos Terhadap Hasil Panen Tomat (Lycopersicum esculentum Mill). Pijar MIPA vol 13 (1): 56 - 59.

Rivai, R,M. dan Wardani, F.F. 2017. Aplikasi Pemanfaatan Pupuk Kompos pada Fase Vegetatif Tanaman Obat Alpinia malaccensis. Proseding Seminar Nasional Masy Biodiv Indon Vol 3 (1): 154 - 156

Sipayung, M., Ashari, H., Baskara, M. dan Heddy, S. 2016. Pengaruh Pemberian Kompos terhadap Pertumbuhan dan Hasil dua Varietas Stroberi (Fragaria, sp). Plantropica Vol 1(2): 35 - 48

Syafriliandi, Murniati dan Idwar. 2016. Pengaruh Jenis Kompos terhadap Pertumbuhan dan 
Produksi Tanaman Jagung Manis. Jom Faperta. Vol 3 (2): 1 - 9

Wasis, B. dan Fathia, N. 2010. Pengaruh Pupuk NPK dan Kompos terhadap Pertumbuhan Semai Gmelina (Gmelina arborea Roxb.). Ilmu Pertanian Indonesia. Vol 16 (2): 123 -129 . 